DOI: 10.33727/JRISS.2019.2.12: 92-100

\title{
Correlation Models on Regional GDP Relative to the Insertion of Graduates on the Labor Market. Forecasts and Estimates
}

\author{
L. Paunescu ${ }^{1}$ \\ ${ }^{1}$ Cybernetics, Information Economy, Finance and Accounting Department, Petroleum\&Gas \\ E-mail: loredana.paunescu@yahoo.com
}

\begin{abstract}
In the analysis we made turned its attention to finding a correlation between GDP and the rate of insertion of university graduates in the economic, regional levels. Analysis shows that there is a correlation between the degree of employability of university graduates and the regional gross domestic product. We hope that this study will be a significant contribution from the regional perspective to better knowledge of the complex relationship between education and employment, may serve to define the strategic role of training and grounding and directing future regional policies on employment and training.
\end{abstract}

Key-words: recalibration, sustenability, educational system, market indicators, labor market, university graduates.

\section{Introduction}

Labor, or rather lack of it, is a growing problem today. Even amid ongoing technological expansion, human resources remain the engine after operating an organization. Unlocking the potential of labor, creating conditions for increasing labor market participation and access to quality jobs are priorities for achieving economic competitiveness, sustainability and inclusion. Amid the difficult conditions caused by the economic crisis plus technological progress and, not least, the aging population, the Romanian economy is facing serious problems in the use of labor, with some distortions in the labor market, which translates the coexistence of a shortage of manpower in certain economic sectors or geographical areas with poor use of its overall.

Financial and economic crisis were manifested in fewer jobs and thus increasing unemployment, by limiting and slowing job creation, with direct consequences in blocking entry of young people into the labor market.

A major challenge in this regard is represented by the unequal distribution of employment, with significant disparities between regions. Despite positive developments in some areas of employment, inactivity rates remain high in less developed areas.

These problems are caused both by general economic context and the weak link of the education system with the actual demand of skills, lack of work experience, which leads to reduced levels of employability of graduates in the labor market. 
The data provided by the National Agency for Employment (NAE), that the first 15 positions of the unemployed, who recently graduated from university, is constant between $2004-2017$, the following occupations: economists, specialists consultants in finance and investments, accounting specialists, etc. The inclusion in specialty graduated or in a related specialization depends on the degree graduated. Graduates of economics, for example, take up jobs rather related specialization graduated.

The reasons invoked graduates related to a post in a different specialization of the graduate, are linked mostly to the lack of availability of a post in the specialization. Almost $80 \%$ of graduates working in another field invoked this reason, other reasons having rather a marginal influence on the decision to engage in a particular job. Taking into account the proportion of those with higher education, we can determine the upward employment with higher education. This is ensured by the increase in activity, and GDP growth. The activity rate has the greatest impact on employment for the period under review, this is normal, mainly due to the direct link between the activity rate and the employment rate of graduates.

In research conducted, the author has turned its attention to analyzing the relationship model of insertion of graduates in the labor market and regional GDP.

The analysis made led to the expected results, namely finding a correlation between the degree of socio-professional insertion of graduates in the labor market and the regional GDP.

The research methodology used in elaborating scientific achievement is evidenced by the following:

$>$ The proposal aims in research;

Making a plan of analysis;

Analysis and interpretation of data;

Correlation performed using the proposed model.

To start scientific research sources used for research were studies and research based on a rich bibliography of articles and papers (attached work), consulting Web site and databases Eurostat, National Statistics Institute (INS), the National Prognosis (CNP), Statistical Yearbook, Eurostat, the National Agency for Employment (NAE), documents from the universities of South-Muntenia and participation in scientific and professional dedicated analyzed domain.

\section{The purpose and objectives in research}

The main objective of the survey is to radiography system capabilities of university education related to employers' expectations in relation to GDP.

This insight on key areas of interest (very valid) hopefully lead to finding and implementing action measures designed to put Romania on the path of sustainable development, which would be translated in the language of economics, the convergence of the GDP to the level of social insertion of young university graduates.

In this respect, we need to, firstly, a better use of the one of the main factors that are part of potential GDP, namely, labor as the only way to stimuli, sustainably increase economic.

\section{Experimental results and discussion}

To test the time evolution of GDP and of the evolution of regional employment rate (MMR) were used as models:

$$
Y(t)=a+b \cdot t+\varepsilon ; \quad t_{2004}=0
$$

where $a$ is the intercept (the intersection of the regression line with the axis OY), $b$ is the slope of the regression line (derived from first order function) and the number of units that changes $Y(t)$ in the modification by one of $\mathrm{t}$, and the residual is variable.

To test the statistical significance of the regression model ANOVA was used methodology for a significance threshold of $\alpha=0.05$ (95\% Confidence Level). 
In order to study dependencies between GDP and MMR in the first phase were analyzed time evolution of the two indicators. If GDP (Figure 1) highlights three distinct periods.

The period 2004-2008 is a period of significant upward trend GDP regression model are:

$Y(t)=39.68+20.2 \cdot t+\varepsilon$

In view of the fact that R2 $=0.9953$, rezltă the model (2) as well approximates the time course of GDP in the first period. The regression coefficient shows an increase of euro 20.2 million regional GDP so that in 2010 regional GDP volume was 2.29 times higher than in 2004.

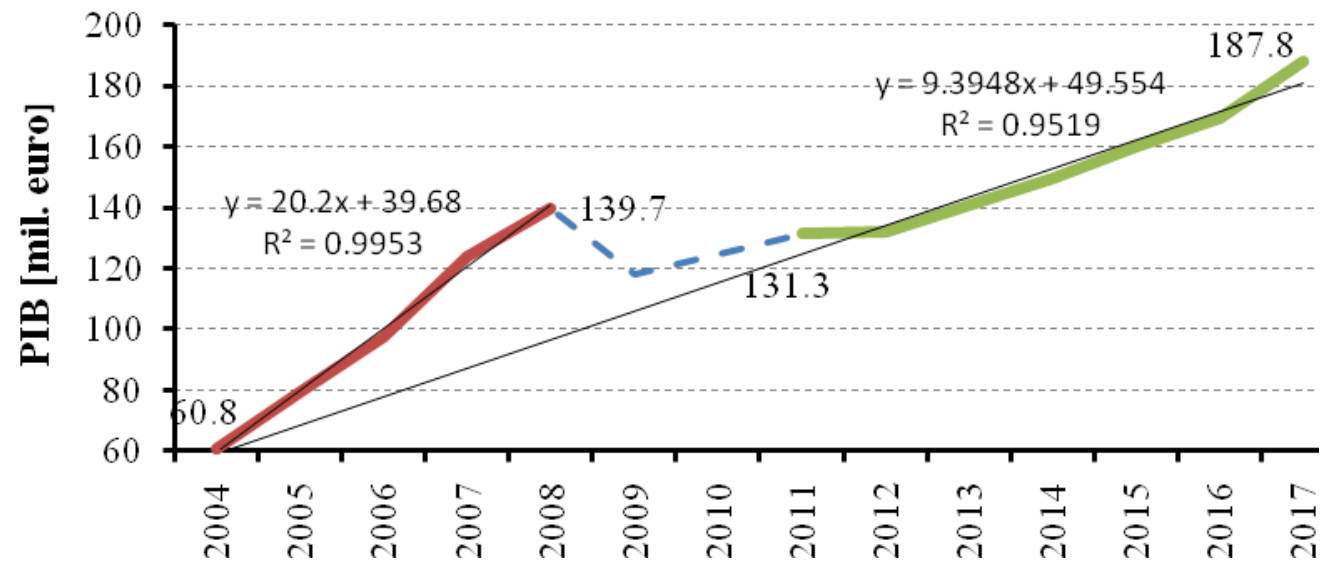

Figure 1. Evolution of GDP during 2004-2017

The second period, between the years 2008 - 2011 is a period of development characterized by alternating a drastic reduction in 2008-2009 and gradually recover in 2009-2011.

The economic crisis that started in 2008 led to a reduction in regional GDP $15.39 \%$, from 139.7 million euros in 2008 to 118.2 million euros in 2009. Although the two years that followed were no increases in regional GDP, with 5.25\% in 2010 compared to 2009 and 5.54\% respectively in 2011 compared to 2010, in 2011, regional GDP in absolute terms continues to be lower than in 2008 by 8.4 million euros.

In the third period, 2011-2017, the regional GDP registered a bottom-up process with an average annual increase of about 9.4 million euros per year, making ICAT in 2017 was 1.43 times higher than in 2011 and 1.35 times higher than in 2008, since the outbreak of the crisis. Regional GDP evolution was linear regression model characteristics are shown in Table 1:

Table 1. Characteristics of the regression model corresponding GDP growth during 2011-2017

\begin{tabular}{|c|c|c|c|c|c|c|c|c|c|}
\hline \multirow{2}{*}{ Multiple R } & \multirow{2}{*}{ R Square } & \multirow{2}{*}{$F$} & \multirow{2}{*}{ Sig. F } & \multirow{2}{*}{\multicolumn{2}{|c|}{ Coefficients }} & \multirow{2}{*}{ t Stat } & \multirow{2}{*}{ P-value } & \multicolumn{2}{|c|}{ 95\% Conf. level } \\
\hline & & & & & & & & Lower & Upper \\
\hline \multirow{2}{*}{0.975} & \multirow{2}{*}{0.951} & \multirow{2}{*}{98.854} & \multirow{2}{*}{0.00018} & $\mathrm{a}$ & 58.948 & 6.117 & 0.00169 & 34.178 & 83.719 \\
\hline & & & & $\mathrm{b}$ & 9.395 & 9.945 & 0.00017 & 6.965 & 11.824 \\
\hline
\end{tabular}

Source: own determinations 
Taking into account the values of the coefficients of the model, as well as the limits of the confidence intervals for a confidence level of $95 \%$, it can be appreciated that in view of the PIP during this period can be described by three shape model (minimum, most likely, respectively, maximum):

$$
\begin{aligned}
& P I B_{\text {min }}(t)=34.178+6.965 \cdot t+\varepsilon \\
& P I B_{c m p}(t)=58.948+9.395 \cdot t+\varepsilon \\
& P I B_{\text {max }}(t)=83.719+11.842 \cdot t+\varepsilon
\end{aligned}
$$

If MMR (Figure 2), it also highlights three distinct periods. Period 2004-2008 is, in this case, a period of increased employment at regional level. The regression model is:

$$
R O R(t)=57.29+1.27 \cdot t+\varepsilon
$$

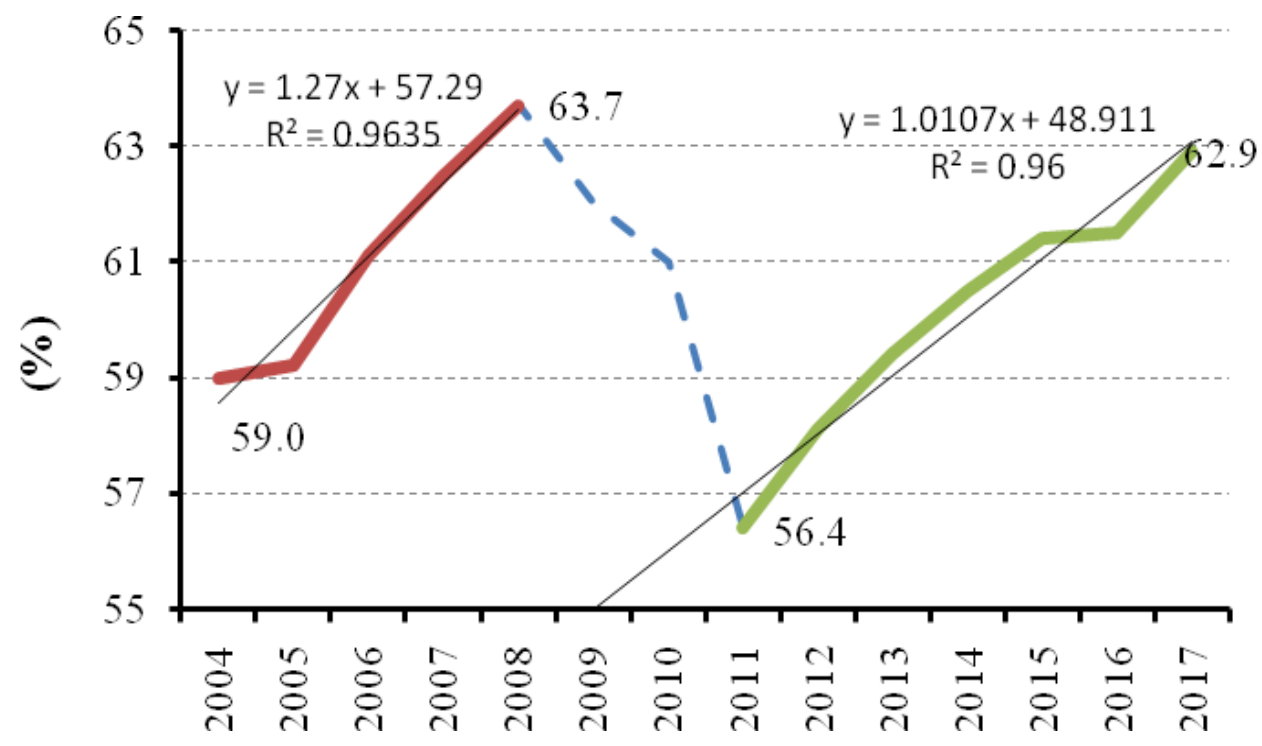

Figure 2. Evolution of regional employment rate

In view of the fact that $R 2=0.9635$, shows that the pattern (4) as well approximates the time course of MMR in the first period. Given that ROR recorded an average annual increase of 1.27 percentage points during 2004-2008 is one beneficial regional where both GDP and ROR evolves upward.

In the second period, 2008-2011, the economic crisis has a strong negative effect on MMR. It decreases continuously with $2.66 \%$ in 2009 compared to 2008 , with $1.63 \%$ in 2010 compared to 2009 and by $7.45 \%$ in 2011 compared to 2010. This significant decrease is ROR in 2011 to record the lowest values in the entire period, 2.6 percentage points less than in 2004.

Third Period 2011-2017 is characterized, in the case of MMR, through continued growth, with average annual growth of 1.01 percentage points. ROR is a linear evolution, the main characteristics of the needles of the regression model are presented in Table 2. Both the values of P-Sig.F and points out that the value is statistically significant regression model. 
Volume 1, Issue 2, 2019

ISSN: 2668-0416

Thoth Publishing House

Table 2. Characteristics of the regression model corresponding ROR development during 2011-2017

\begin{tabular}{|c|c|c|c|c|c|c|c|c|c|}
\hline \multirow{2}{*}{ Multiple R } & \multirow{2}{*}{ R Square } & \multirow{2}{*}{$F$} & \multirow{2}{*}{ Sig. F } & \multirow{2}{*}{\multicolumn{2}{|c|}{ Coefficients }} & \multirow{2}{*}{ t Stat } & \multirow{2}{*}{$P$-value } & \multicolumn{2}{|c|}{$95 \%$ Conf. level } \\
\hline & & & & & & & & Lower & Upper \\
\hline \multirow{2}{*}{0.979} & \multirow{2}{*}{0.960} & \multirow{2}{*}{120.073} & \multirow{2}{*}{0.00011} & $\mathrm{a}$ & 49.921 & 53.072 & $4.49 \mathrm{E}-08$ & 47.503 & 52.339 \\
\hline & & & & $\mathrm{b}$ & 1.011 & 10.9578 & 0.00011 & 0.773 & 1.247 \\
\hline
\end{tabular}

Source: own determination

Given the limits of confidence intervals resulting in this case three models that highlight the lower, most likely and greater development of ROR for a 95\% confidence coefficient $(\alpha=0.05)$ :

$$
\begin{aligned}
& \operatorname{ROR}_{\text {min }}(t)=47.503+0.773 \cdot t+\varepsilon \\
& \operatorname{ROR}_{c m p}(t)=49.921+1.011 \cdot t+\varepsilon \\
& \operatorname{ROR}_{\text {max }}(t)=52.339+1.247 \cdot t+\varepsilon
\end{aligned}
$$

Analyzing both traectoriile evolution of GDP and ROR during 2011-2017, and the characteristics of regression models (3) and (5) was tested dependence of regional GDP and ROR. For such it was used a linear model of the form:

$$
\operatorname{PIB}(R O R)=a+b \cdot R O R+\varepsilon
$$

For the period 2011-2017 model characteristics are shown in Table 3. In view of the fact that Sig.F $=0.00243<\alpha=0.05$ that is statistically significant regression model. Also values P-value model highlighted that both coefficients are statistically significant, as evidenced by the values of the Lower

\begin{tabular}{|c|c|c|c|c|c|c|c|c|c|}
\hline \multirow{2}{*}{ Multiple R } & \multirow{2}{*}{ R Square } & \multirow{2}{*}{$F$} & \multirow{2}{*}{ Sig. $F$} & \multirow{2}{*}{\multicolumn{2}{|c|}{ Coefficients }} & \multirow{2}{*}{$t$ Stat } & \multirow{2}{*}{$P$-value } & \multicolumn{2}{|c|}{ 95\% Conf. level } \\
\hline & & & & & & & & Lower & Upper \\
\hline \multirow{2}{*}{0.929} & \multirow{2}{*}{0.864} & \multirow{2}{*}{31.837} & \multirow{2}{*}{0.00243} & $\mathrm{a}$ & -386.05 & -3.984 & 0.01048 & -605.525 & -130.582 \\
\hline & & & & $\mathrm{b}$ & 8.678 & 5.642 & 0.00243 & 4.725 & 12.632 \\
\hline
\end{tabular}
and Upper confidence interval (within each interval have the same sign).

Table 3. The characteristics of the regression model of the form (6) corresponding to the period 2011-2017

Source: own determinations

Three model variants characterizing the dependence of regional GDP and MMR are:

$$
\begin{aligned}
& P I B_{\text {min }}(R O R)=-605.525+4.725 \cdot R O R+\varepsilon \\
& P I B_{\text {cmp }}(R O R)=-386.05+8.678 \cdot R O R+\varepsilon \\
& P I B_{\text {max }}(R O R)=-130.582+12.632 \cdot t+\varepsilon
\end{aligned}
$$

Models (7) shows that the value changes by one unit ROR regional GDP values change with a value between 4.723 million euros and 12.634 million euros, the most likely value is 8.678 million euros. Given this and given the fact that the models (5) values MMR may be between 0.773 and 1.247 percentage points, the most likely value being 1.011 percentage points values could be expected forecast for 2018 are presented the decision matrix Aij in table 4. 
Table 4. Decision matrix to estimate regional GDP in 2018

\begin{tabular}{|c|c|c|c|}
\hline$A_{i j}$ & GDP_min & GDP_cmp & GDP_max \\
\hline$\Delta$ ROR_min & 191.452 & 194.515 & 197.565 \\
\hline$\Delta$ ROR_cmp & 192.577 & 196.583 & 200.571 \\
\hline$\Delta$ ROR_max & 193.692 & 198.633 & 203.552 \\
\hline
\end{tabular}

Source: own determinations

The research carried out we can see that economic developments have a powerful social, as in social developments and results are reflected on the medium and long term economy.

Given this and given the fact that the models (5) values MMR may be between 0.773 and 1.247 percentage points, the most likely value being 1.011 percentage points forecast values for 2018 are derived from the GDP regional in year 2017 as follows:

$$
P I B_{2018, x}(R O R)=P I B_{2017}+b_{x} \cdot \Delta R O R_{x}+\varepsilon
$$

In the model $(8) \mathrm{x}$ corresponds to the three situations $\left(\min \mathrm{cm}^{2}, \max \right)$ and $\Delta \mathrm{ROR}$ is the projected annual mean change of MMR. In these conditions forecasted values for 2018 are presented in Table 5:

Table 5. Predicted values of regional GDP for 2018 (EUR million)

\begin{tabular}{|c|c|c|}
\hline PIB_min & PIB_cmp & PIB_max \\
\hline 191.452 & 196.583 & 203.552 \\
\hline
\end{tabular}

Source: own construction

The forecast shows that the most likely value is 196583 euros milioade plus / minus 6.97 million euros (plus / minus 3.55\%) for a confidence level of $95 \%(\alpha=0.05)$.

Given that the series of data on which the forecast is made very short, forecast, more or less true for 2019 is relatively unlikely. However, assuming the hypothesis (unlikely in the current social and economic context) that other factors influencing regional GDP developments do not change the values of regional GDP forecast for 2019 were determined by the pattern:

$$
P I B_{2019, x}(R O R)=P I B_{2018, x}+b_{x} \cdot \Delta R O R_{x}+\varepsilon
$$

2018 predicted values are shown in Table 6 :

Table 6. Predicted values of regional GDP for 2019 (EUR million)

\begin{tabular}{|c|c|c|}
\hline PIB_min & PIB_cmp & PIB_max \\
\hline 195.105 & 205.365 & 219.304 \\
\hline
\end{tabular}

Source: own construction

Analyzing developments expected on the medium and long term, the development of Gross Domestic Product and employment of university graduates in the perspective of 2019, we consider that both GDP and employment rate higher level of education, Nestle regional fluctuated irregularly period. 


\section{Conclusions}

Analysis aimed at regional level, the degree of labor market insertion of university graduates linked to the GDP.

Taking such a perspective, the forecast for 2019 is that it is based on the predicted values for 2018, values determined for a confidence level of $95 \%$. Given this level of confidence for regional GDP figures forecast for 2019 is over $90 \%(0.95 * 0.95)$.

Precisely for this reason, incidence level of socio-professional insertion of young university graduates cause the creation of self, that maturity.

Also employment of labor will increase slightly in the future, mainly due to projected increase in GDP. I think it would be appropriate, for 2020, a smart, (characterized by strengthening knowledge through innovation, education and through a digital society), sustainable growth (by increasing competitiveness), an inclusive growth (through increased participation in the labor market and acquire new professional skills) and an optimal level of GDP investment in R \& D.

In this respect, short-term, attention will be directed towards the development of human capital and increase competitiveness by linking education and lifelong learning with the labor market and ensuring better opportunities for future participation on a modern and flexible labor market. Medium and long term, by 2020, an important role will education and training.

\section{Authors'contributions}

The proposed solution as an indicator fails to provide the necessary support to validate the possibility that an optimum design work necessary to obtain vital advance the process of catching up with the developed countries.

This work complements the research in this field in recent years found to be of great value, but infinitely more effective together. Made personal contribution to research is to analyze the relationship model of insertion of graduates in the labor market and regional GDP.

\section{Proposals and recommendations}

For a positive impact regionally on university education harmonious correlation with the requirements of the labor market and gross domestic product, we suggest the following:

2. an integrated system that includes all real-time information from previous systems designed and universities;

3. providing a true picture of human capital developed by higher education;

4. implementation of educational policies of the European Union;

5. support to strengthen relations between universities, students, graduates and socio-economic environment, promoting the exchange of experience and contribution to the construction of virtual communities;

6. support the exchange of information between actors in higher education and socio-economic environment.

Higher education institutions must be in increasingly connected to the social environment and maintain regular contact with various communities and organizations who expect services clearly formulated, graduates with a high degree of specialization. In the research work we intend to draw attention to:

$>$ supporting a flexible approach to university curricula in line with labor market demand;

encouraging continuous learning based on intellectual and vocational development;

$>$ promoting cooperation between business and education as key areas in socio-economic regeneration of the whole region;

$>$ infrastructure development counseling and retraining;

$>$ training programs to provide a much higher degree of adaptability to the new requirements of the labor market. 
Also consider continuous adaptation and structuring appropriate university education system and training. The aim is to create an ideal framework for education and training opportunities for labor, while removing barriers to accessing them. The major impact will be to increase the level of integration of the labor force, reducing unemployment, creating new jobs, new business development and increased social stability. We believe that the increasing educational and vocational training, or to improve the conditions for lifelong learning, namely, access and the employment of university graduates, would require:

$\checkmark$ development of tools for monitoring the route socio - professional university graduates,

$\checkmark$ improving the quality of teaching by linking the educational offer, skills, competences and skills acquired by graduates of higher education with labor market needs;

$\checkmark$ evidenced on professional development at different intervals of time after graduation, correlated with a number of socio-biographical and educational descriptors (feedback necessary for improvement of the university);

$\checkmark$ regular monitoring of socio-professional insertion of graduates in order to improve the relevance of educational offer of higher education to labor market demand and improve the quality of students' training;

$\checkmark$ developing and strengthening institutional capacity to perform these periodic surveys, the relevant timeframe;

$\checkmark$ knowing capacity supply educational system and its correlation with the estimated requirements of the labor market;

$\checkmark$ decision making at national and institutional level on the implementation of national policies on employment;

$\checkmark$ responsibility of social partners in education issues;

$\checkmark$ efficient investment in human resources (graduated) reflected by the higher education system results.

Thus regionally, these proposals may have the impact of increasing long-term employment, economic efficiency, and increased social stability.

The restructuring of the regional economy and globalization has created in the region analyzed situations where training an important part of labor is outdated or unsatisfactory, with implications in terms of unemployment and economic activity performance. However, economic changes have a radical effect on the nature of the work and training of labor.

\section{References}

[1] Aceleanu, M.I. 2011 Lifelong Learning Necessity For Romanian Labour Market Flexibility, Proceedings of the 6th International Conference on Business Excellence, Vol 2;

[2] Aceleanu M. I.,T 2011 The Relationship Between Education And Quality Of Life Implications Of The Labour Market In Romania, Journal of International Scientific Publications, Vol 9, Part 2;

[3] Angelescu, A. 2001 Mediul ambiant şi dezvoltarea durabilă, Editura A.S.E. ,Bucureşti;

[4] Angelescu C.2004 Stănescu I., Politica de creştere economică, Bucureşti, Editura Economică;

[5] Datalo, A. 2010Strategies to Approximate Random Sampling and Assignment, Oxford: Oxford University Press;

[6] Dávila Gómez, A. M. 2012 Crowther D., Human Dignity and Managerial Responsibility: Diversity, Rights, and Sustainability, Gower Publishing, Ltd., England;

[7] Dobre, M.H. 2006 Aceleanu, M.I., Negoitei, I., Rolul educaţiei în inserţia tinerilor pe piaţa muncii. Cazul României, Facultatea de Economie;

[8] Ehnert, Ina (Dr.) 2009 Sustainable Human Resource Management: A Conceptual and Exploratory Analysis from a Paradox Perspective, Germany: University of Bremen;

[9] Gal, D 2002 Educaţia şi mizele ei sociale, Editura Dacia, Cluj-Napoca;

[10] Georgescu, M. A. 2005 Provocări socio-economice, Ed.Casa Cărţii de Ştiinţă, Cluj Napoca; 
[11] Osoian, C 2005 Piaţa forţei de muncă, Editura Dacia, Cluj Napoca;

[12] Popescu Constanta, Păunescu V. Loredana-Maria 2014 The Evolution, Bloking Steps and New Trands on The Romanian Labour Market, Analele Universitatii Constantin Brancusi din Targu Jiu, seria Economie (lucrare prezentata in cadrul Simpozionului Societatea informationala si dezvoltarea durabila, desfasurat in 4-5 aprilie la Ranca, Gorj);

[13] Popescu,I.A., Bondrea A.A., Constantinescu M.I 2005 Dezvoltarea durabilă. O perspectivă românească, Ed. Economică, Bucureşti;

[14] Răboacă, Gh. 2003 Piaţa muncii şi dezvoltarea durabilă, Editura Tribuna Economică, Bucureşti;

[15] Şerban, M., Pataki, I 2004 Oportunitatea constituirii unui mecanism regional de dialog social în sprijinul creşterii ocupării forţei de muncă, Bucureşti: Humanitas Educaţional;

[16] Voiculescu, V 2008 Educaţia în economia de piaţă, Iaşi: Editura Institutul European;

[17] Zamfir, C., Stoica, L 2006 O nouă provocare: Dezvoltarea socială, Editura Polirom, Iaşi.

\section{Statistical data sources}

[18] Institutul Naţional de Statistică al României, https://statistici.insse.ro/shop/

[19] Anuarul Statistic al României;

[20] Ancheta Forţei de Muncă în Gospodării - AMIGO, buletin trimestrial. 